

RESEARCH ARTICLE

\title{
THE INHIBITORY EFFECT OF NEWLY SYNTHESISED GUAR EPOXY N-METHYL PIPERAZINE ON THE GROWTH OF PATHOGENIC BACTERIA AND FUNGI.
}

\author{
Richa Chauhan* and Sangeeta Loonker. \\ Department of Chemistry, Jai Narain Vyas University, Jodhpur (Rajasthan),-342001, India.
}

\section{Manuscript Info}

Manuscript History

Received: 12 December 2016

Final Accepted: 27 January 2017

Published: February 2017

Key words:-

GE-MP, antibacterial activity, antifungal activity and inhibition zone.

\begin{abstract}
Guar based derivative was synthesised. The inhibitory activity of the newly synthesised derivative against pathogenic bacteria such E.coli, Klebseilla pnemoniae, Pseudomonas aeruginosa, Staphylococcus aureus and some strains of fungi such as C. kefyr, C. tropicalis, $C$. glabrata, C. auris, Geotricum candidum, Rhodoturula, C. parapsilosis, C. albicans was evaluated. The new resin was characterized by FT-IR, 1HNMR, XRD, Mass spectra and elemental analysis. Other resin characteristics like swelling, moisture content, bulk density and specific bulk volume were also studied. The antimicrobial activity was carried out by well diffusion method.
\end{abstract}

Copy Right, IJAR, 2017,. All rights reserved.

\section{Introduction:-}

Guar gum is a galactomannan biopolymeric material isolated from the endosperms of Cyamopsis tetragonoloba, which is native to north-western parts of India(1).Guar seed endosperm is a source of water soluble gum which is used as stabilizer, emulsifier and thickener in various food products and contributes to soluble dietary fiber portion of seed total dietary fiber (2). Its stability and solubility as well as its sorption capacity can be altered through functionalization by organic group and chelating agent. The ion exchangers based on guar gum powder is hydrophilic and biodegradable, whereas other ion exchangers prepared from petrochemical product are not hydrophilic and biodegradable. Due to rising prices of petroleum products the guar gum powder has been selected for development of guar gum resin, which are of low cost as they are locally available in large quantities from agriculture resources and these biopolymers are eco-friendly (3).Nowadays, microbial infections are a great concern because they are one of the main primary causes of death worldwide, especially in healthcare institutions, where people are generally more vulnerable (4-6). This fact is mainly due to the persistence of potentially pathogenic microbes(bacteria, viruses and fungi) in several locations, such as textiles, healthcare products, medical devices, water purification systems, sanitation facilities, among others (7,8).A variety of micro-organisms, including

E.coli, Pseudomonas aeruginosa and Staphylococcus aureus etc. may lead to food spoilage which is one of the most important concern for food industry (9). Most microbes are harmful and can cause numerous disease infections such as diarrhoea, respiratory illness, whooping cough and fever (10).

Antimicrobial polymers, also known as polymeric biocides are a class of polymer having the ability to inhibit the growth of micro-organisms such a bacteria, fungi or protozoans (11). The use of polymers as antimicrobial agents presents several advantages, since these products usually exhibit long-term activity and limited residual toxicity, are chemically stable, non-volatile and do not permeate through skin(7,12).Guar when crosslinked, inhibits and suppresses microbial activities, due to complexation with the crosslinking agent. This interaction caused disruption 
on the microbial cells, which then changed their metabolism and led to cell death $(13,14)$.

The aim of the present study is to synthesise guar based derivative ie. Guar epoxy n-methyl piperazine (GE-MP) and to investigate the inhibitory effect of the newly synthesized derivative against some pathogenic bacteria such as E.coli, Klebseilla pnemoniae, Pseudomonas aeruginosa, Staphylococcus aureus and fungi such as $C$. kefyr, C. tropicalis, C. glabrata, C. auris, Geotricum candidum, Rhodoturula, C. parapsilosis and C. albicans. It was characterized by FT-IR, 1HNMR, XRD, Mass spectra and elemental analysis. Other resin characteristics like swelling, moisture content, bulk density and specific bulk volume were also studied.

\section{Material and Methods:- Material:-}

Guar(200 mesh size) was procured from local industry. All AR grade chemicals used were procured from Sigma,Loba Chemicals and Ases Chemical Works. The antimicrobial strains were obtained from Dr. S. N Medical College, Jodhpur(Rajasthan), India.

Synthesis of Guar epoxy n-methyl piperazine (GE-MP):-

The synthesis of GE-MP is carried out in two steps:

\section{Preparation of epoxy ether of guaran:-}

1 mole of guaran powder was slurried in dioxane solvent in a round bottom flask. Then $50 \%$ aqueous $\mathrm{NaOH}$ was added in the slurry to make the reaction mixture alkaline, and the mixture was constantly magnetically stirred at $45^{\circ} \mathrm{C}$ for 2 hours. Further 1 mole of epichlorohydrin was added gradually with continuous stirring and the $\mathrm{pH}$ was adjusted to 10 then this reaction mixture was refluxed with continuous stirring for another 4 hours. The whole reaction was carried out at $45^{\circ} \mathrm{C}$. Later, the compound was filtered on vacuum pump with $80 \%$ aqueous methanol containing few drops of nitric acid to remove inorganic impurities of chloride ion and excess of alkali and then the compound formed was oven dried and used for further derivatisation.(FigureI)

\section{Synthesis of Guar epoxy ether of n-methyl piperazine:-}

The formed epoxy ether of guar was slurried in dioxane and $50 \%$ sodium hydroxide $(\mathrm{NaOH})$ under reflux, upon constant magnetic stirring at $45^{\circ} \mathrm{C}$ and $\mathrm{pH}$ was adjusted to 9-10. 0.02 moles on $\mathrm{n}$ - methyl piperazine was then added to the reaction mixture. The whole reaction mixture was refluxed and stirred for 5-6 hours at $45^{\circ} \mathrm{Con}$ the water bath. The formed compound was washed with $50 \%$ methanol. Then the air dried compound was suspended in $0.1 \mathrm{~N} \mathrm{HCl}$, after filtering it was successively washed with $0.1 \mathrm{~N} \mathrm{NaOH}$ and $0.1 \mathrm{NHCl}$ and then final washing was done with $100 \%$ ethanol and dried under vacuum.(FigureII)

\section{Characterization of newly synthesised GE-MP:-}

The GE-MP formed was characterized using swelling and water regain, moisture content, bulk density, bulk volume, elemental analysis, FTIR, XRD, NMR, and mass spectroscopy.

\section{Swelling and water Regain:-}

GE-MP is of polar nature and it swells in polar solvent. Water regain refers to the weight of water taken up by 1 gram of dry resin.

Water regain is given by:- $\mathrm{W}_{\mathrm{r}}=\left(\mathrm{W}_{1}-\mathrm{W}_{2}\right) / \mathrm{W}_{2}$

Here, $\mathrm{W}_{1}=$ Weight of wet substance (in grams)

$\mathrm{W}_{2}=$ Weight of dry substance (in grams)

\section{Moisture Content:-}

1 gram of GE-MP was dried to a constant weight in a vacuum desiccator at $40^{\circ} \mathrm{C}$ overnight and then weighed. Percentage of $\mathrm{MC}=\left(\mathrm{W}_{1}-\mathrm{W}_{2}\right) \times 100$

Here, $\mathrm{W}_{1}=$ weight of resin before keeping in desiccator

(1g) $\mathrm{W}_{2}=$ weight of resin after keeping in desiccator

\section{Bulk density and Specific bulk volume:-}

$1 \mathrm{~g}$ of GE-MP was dried to a constant weight and poured in a $1 \mathrm{~cm}^{3}$ measuring cylinder. Then the cylinder was thrashed gently on the surface until the volume of the resin remains same.

Bulk density $=1 /($ specific bulk volume $)$ 


\section{Elementary Analysis:-}

The elementary Nitrogen content was determined using standard method.

\section{FT-IR Analysis:-}

The FTIR spectra of GE-MP formed was analysed using AT-IR(ALPHA EX Bruker) spectrophotometer in range of $400 \mathrm{~cm}^{-1}$.

\section{XRD Analysis:-}

The crystal structure of GE-MP was characterized using X-ray diffractometer (XRD , Bruker D8 advance) with Cu $\mathrm{K}$ $\alpha$ radiation. $(\lambda=1.54 \AA)$ as $x$-ray source, it was operated at $40 \mathrm{~mA}$ and $40 \mathrm{KV}$ in the range of $2 \Theta=20-800$.

\section{NMR Analysis:-}

1HNMR characterization was proceeded on Bruker Advance(500MHz) at 297-303K.

\section{Mass Spectra Analysis:-}

The mass spectra of the new guar derivative was studied using Thermo Scientific TSQ 8000 Gas Chromatograph with Ion Source Type of EI source programmable to $350^{\circ} \mathrm{C}$ and with mass range of $2.1100 \mathrm{amu}$.

\section{Antimicrobial Activity:-}

The pathogenic bacteria and fungi were isolated from Dr. S.N Medical College, Jodhpur(Raj), India. They were maintained as pure culture in specific agar medium and were preserved by sub culturing every 6 month. The present study includes the study on pathogenic bacteria and fungi. If certain bacteria and fungi are resisted by any antimicrobial agent then it stops the growth of that particular bacteria and fungi and a zone is created where the growth of bacteria or fungi is not visible, this zone is known as zone of inhibition. Zone of Inhibition testing is a quick, qualitative means to measure the ability of an antimicrobial agent to inhibit the growth of microorganisms. In the world of antimicrobial substances, the degree to which these materials are inhibitory can be of greatly importance to the health of the consumer. The pathogenic strains of bacteria used in the present study are E.coli, Klebseilla pnemoniae, Pseudomonas aeruginosa, Staphylococcus aureus and the strains of fungi used are C. kefyr, C. tropicalis, C. glabrata, C. auris, Geotricum candidum, Rhodoturula, C. parapsilosis, C. albicans.

\section{Preparation of Inoculum:-}

Pure isolate of each bacterium and fungi were first subcultured in nutrient broth at $37^{\circ} \mathrm{C}$ for $24 \mathrm{~h}$. With this method, approximately 100 microlitres of standard inoculums from a single strain was spread over an agar plate using a sterile swab. By using a sterile swab, a suspension of the pure culture is spread evenly over the face of a sterile agar plate.

\section{Antimicrobial sensitivity test using well diffusion method:-}

In well diffusion method, wells of certain diameter are dig on the sterile agar plate. Then the resin is filled in the well using micropipette, then they were incubated. If the bacterial or fungal strain is susceptible to the antimicrobial agent, then a zone of inhibition appears on the agar plate. The diameter of inhibition zone formed was measured in $\mathrm{mm}$ with transparent ruler and the results were recorded.

\section{Results and Discussion:-}

The characteristic property of newly synthesised GE-MP is shown in tabular form (Table I) which gives the information about the physiochemical property of the resin. Spectral analysis gives the exact idea about the structure and information about the functional group incorporated in the newly synthesised derivative of guar. The relevant data shows that the desired functional group has been crosslinked with guar.

The spectral data is analysed as:

FT-IR interpretation (Figure III): FT-IR spectrum of GE-MP resin shows a distinct peak at $3420.23 \mathrm{~cm}^{-1}$ which is characteristic peak for N-H stretching. The band at $2922 \mathrm{~cm}^{-1}$ denotes $\mathrm{sp}^{3} \mathrm{C}-\mathrm{H}$ stretching vibrations. Peaks at $1654.08 \mathrm{~cm}^{-1}$ and $1383.27 \mathrm{~cm}^{-1}$ corresponds to $\mathrm{N}-\mathrm{H}$ bending and $\mathrm{C}-\mathrm{N}$ stretching vibrations respectively. Another weak peak of $1096.27 \mathrm{~cm}^{-1}$ attributes to phenyl C-O stretching. 
XRD interpretation(FigureIV): The XRD data indicates that n-methyl piperazine is loaded onto the surface of epoxy ether of guar. Actual XRD spectra of guar shows that it is amorphous in nature but upon complexation it may

become crystalline or semicrystalline. The spectra reveals that the structure of GE-MP resin is triclinic and its crystalline size is $96.9 \AA$.

1HNMR interpretation(Figure V): The characteristic peak at $\delta=2.26-2.08$ appears due to $-\mathrm{N}-\mathrm{CH}_{3}$ and other peaks at $\delta=1.70$ appears due to $-\mathrm{CH}_{2}-\mathrm{N}$. Signal at $\delta=3.0-5.3$ is due to $-\mathrm{CH}_{2}$ of $-\left(\mathrm{CH}_{2}-\mathrm{O}-\mathrm{R}\right)-$ moiety. The resin was dissolved in $\mathrm{CDCl}_{3}$ solvent for spectral analysis.

Mass interpretation(FigureVI): M+ (247.2)

\section{Antimicrobial Activity:-}

The results of the antimicrobial activity of the newly synthesised GE-MP against bacterial and fungal strains are given in table II and table III. The present study depicts that different micro-organisms respond differently towards the newly synthesised resin, as a result different measurement of diameter of inhibition zone for different microorganisms were recorded. Pure guar do not show antimicrobial activity but upon complexation it may or may not show response towards the microbes. In the present research GE-MP resin shows positive inhibition zone for antibacterial activity and antifungal activity, in all four bacterial strains and five out of eight fungal strains. GE-MP shows small inhibition zone for E.coli, Pseudomonas aeruginosa and Klebseilla pnemoniae and S.aureus (figure VII A). Some fungi like C. glabrata, Rhodoturula, C. parapsilosis, Geotricum candidum and C.auris shows positive inhibition zone while C.kefyr, C.tropicalis, C.albicans do not shows antifungal activity (figure VII B). The results of the present study are quite encouraging as it exhibited antimicrobial activity against pathogens.

\section{Conclusion:-}

The newly synthesised derivative of guar, GE-MP was synthesised by using natural base with nontoxic reagents hence it is environment friendly in nature. Also they show sufficiently effective antibacterial and antifungal activity against microbes and can be of great importance to the health of the consumer.

\section{Acknowledgement:-}

The authors are thankful to Department of Science \& Technology, India for their financial assistance in the work. Thanks are also to the SAIF(Sophisticated Analytical Instrument Facility), CDRI(Central Drug Research Institute), Chandigarh(India) for mass spectral analysis and Indian Institute of Technology, Jodhpur(India) for NMR and XRD spectral analysis. Authors are also grateful to Dr. S.N Medical College, Jodhpur(India) for their guidance and assistance in conducting Antimicrobial activity.

Table I:- Characteristic property of newly synthesised derivative of Guar(GE-MP)

\begin{tabular}{|c|c|}
\hline Characteristic property & GE-MP resin \\
\hline 1. Water regain & 0.66 \\
\hline c. Moisture content & 2.7 \\
\hline 3. Bulk volume & $2.0 \mathrm{cc} / \mathrm{g}$ \\
\hline 4. Nitrogen content (\%) & $15 \%$ \\
\hline
\end{tabular}

Table II:- Inhibition zone of GE-MP resin against pathogenic bacteria

\begin{tabular}{|c|c|c|}
\hline S.no & Bacteria used & Inhibition Zone \\
\hline 1 & Escherichia coli & $1 \mathrm{~mm}$ \\
\hline 2 & Klebseilla pnemoniae & $1 \mathrm{~mm}$ \\
\hline 3 & Psuedomonas aeruginosa & $1 \mathrm{~mm}$ \\
\hline 4 & Staphylococcus aureus & $1 \mathrm{~mm}$ \\
\hline
\end{tabular}


Table III:- Inhibition zone of GE-MP resin against some fungi

\begin{tabular}{|c|c|c|}
\hline S.no & Fungi used & Inhibition Zone \\
\hline 1 & Candida kefyr & $-\mathrm{e}$ \\
\hline 2 & Candida tropicalis & $-\mathrm{e}$ \\
\hline 3 & Candida glabrata & $4 \mathrm{~mm}$ \\
\hline 4 & Candida auris & $1 \mathrm{~mm}$ \\
\hline 5 & Geotricum candidum & $3 \mathrm{~mm}$ \\
\hline 6 & Rhodoturula & $3 \mathrm{~mm}$ \\
\hline 7 & Candida parapsilosis & $2 \mathrm{~mm}$ \\
\hline 8 & Candida albicans & $-\mathrm{ve}$ \\
\hline
\end{tabular}

$$
\underset{\text { Guar }}{\mathrm{Guar}} \frac{\mathrm{s}}{\mathrm{C} \mathrm{CH}_{2} \mathrm{OH}}+\mathrm{Cl}-\mathrm{CH}_{2}-\underset{\text { Ephichlorohydrin }}{\mathrm{CH}}-\mathrm{O}^{-\mathrm{CH}_{2}}
$$

$$
\begin{aligned}
& \downarrow \mathrm{NaOH} \\
& \text { Guar } \frac{5}{3} \mathrm{CH}_{2}-\mathrm{CH}_{2}-\underset{\mid}{\mathrm{CH}}-\mathrm{CH}_{2}-\mathrm{Cl}
\end{aligned}
$$

Chlorohydrin of Guar<smiles>[14CH3]O</smiles>

Guar $\frac{5}{3} \mathrm{CH}_{2}-\mathrm{O}-\mathrm{CH}_{2}-\underset{\mathrm{O}}{\mathrm{C}}-\mathrm{CH}_{2}$

Epoxy ether of Guar

(Figure I) Preparation of epoxy ether of Guar

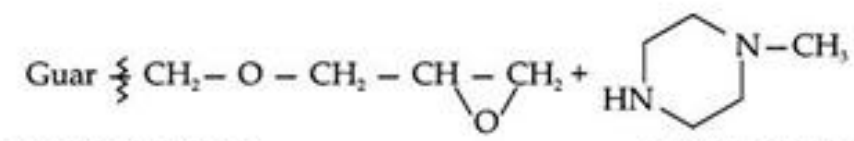

Epoxy Ether of Guar

$\mathrm{n}$-Methyl Piperazine

$$
\left.45^{\circ} \mathrm{C}(5-6 \mathrm{hrs})\right\rfloor \text { Dioxane }+\mathrm{NaOH}
$$<smiles>CCCOCC(O)CN1CCN(C)CC1</smiles>

(Figure II) Synthesis of GE-MP resin 


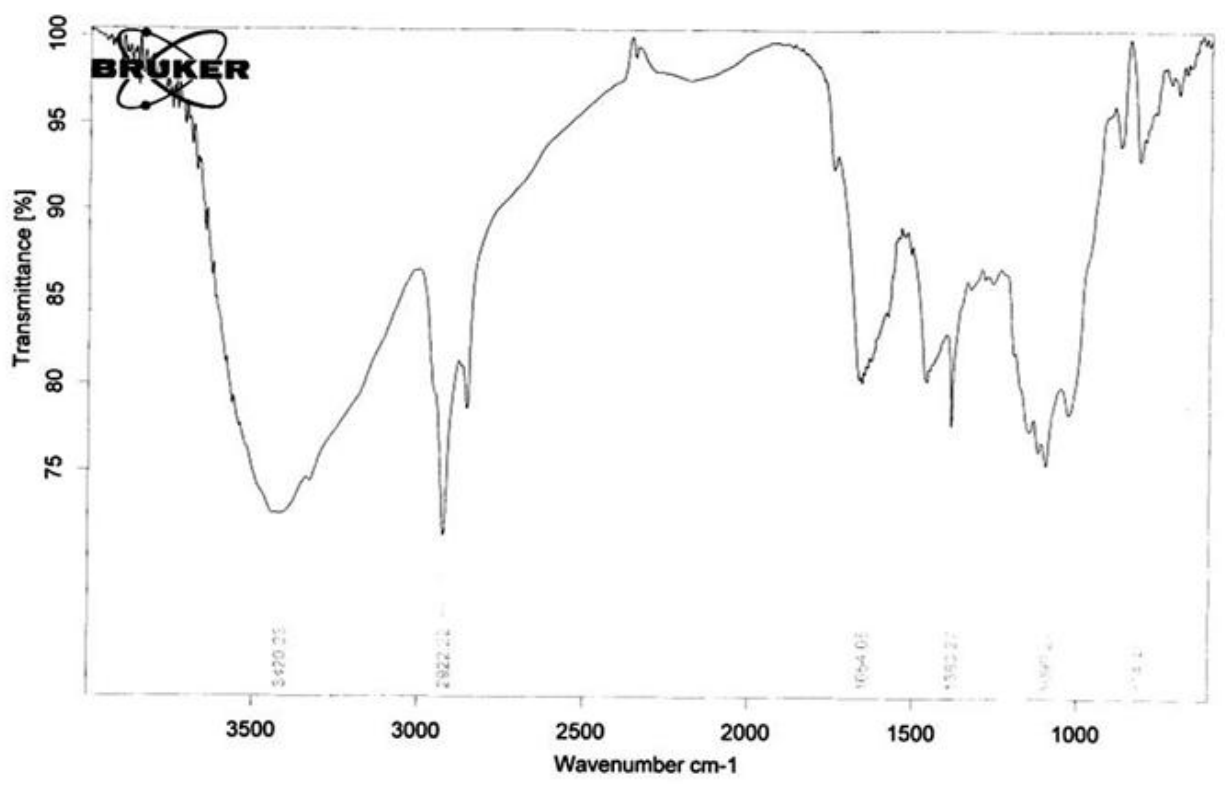

Figure III:- FT-IR spectra of GE-MP

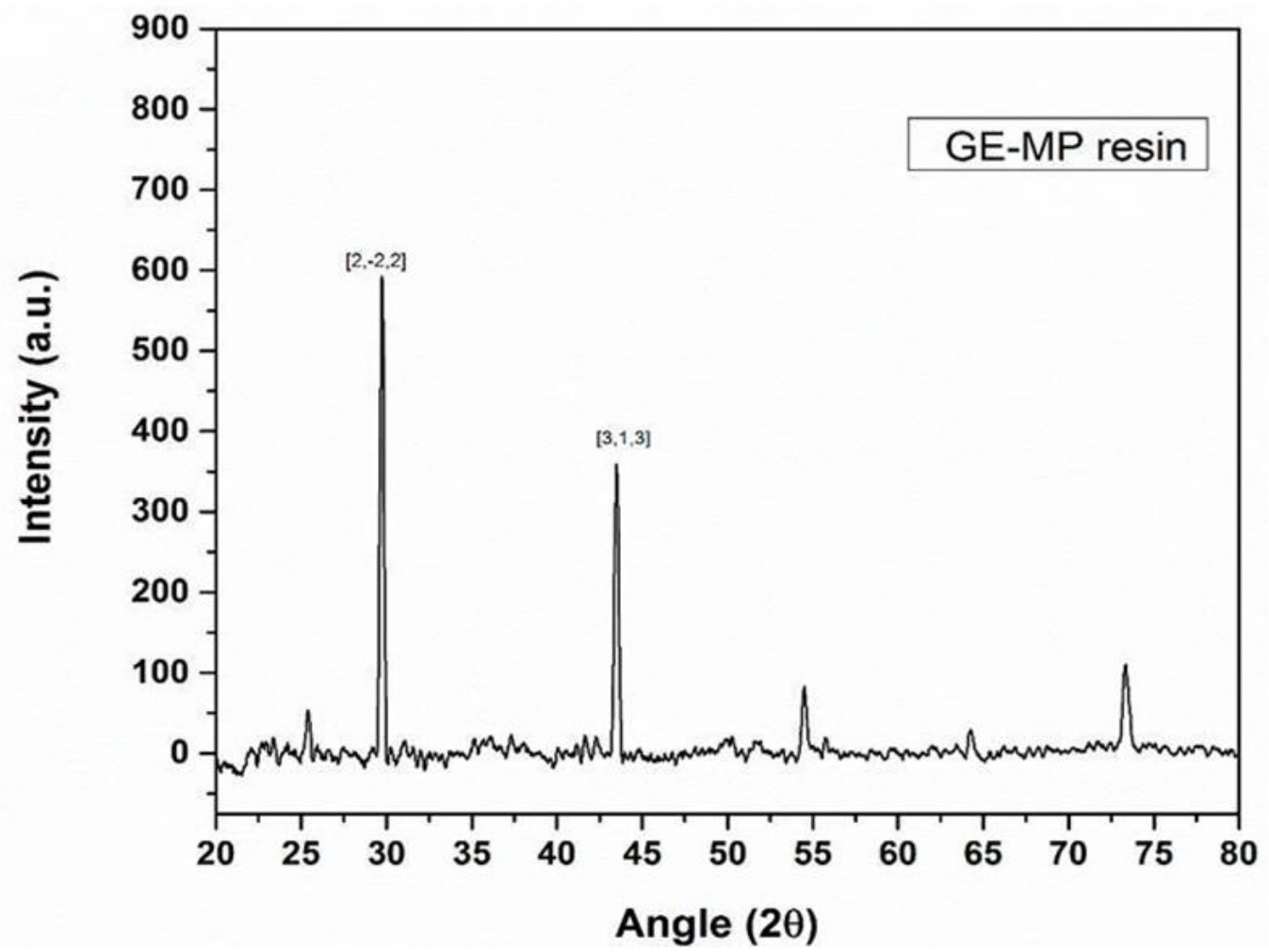

Figure IV:- XRD spectra of GE-MP 


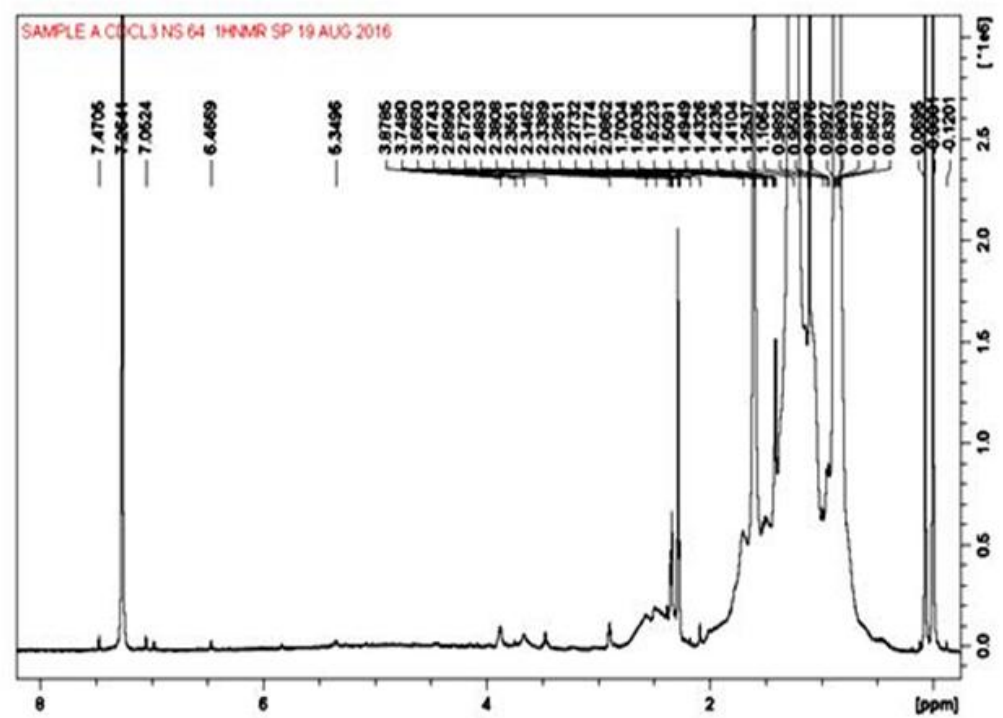

Figure V:- 1HNMR spectra of GE-MP

C \#497 RT: 1.72 AV: 1 AV: 5 SB: 12 490-495 499-504 NL: 4.13E7

$\mathrm{T}:+\mathrm{c}$ El Full ms [50.000-600.000]

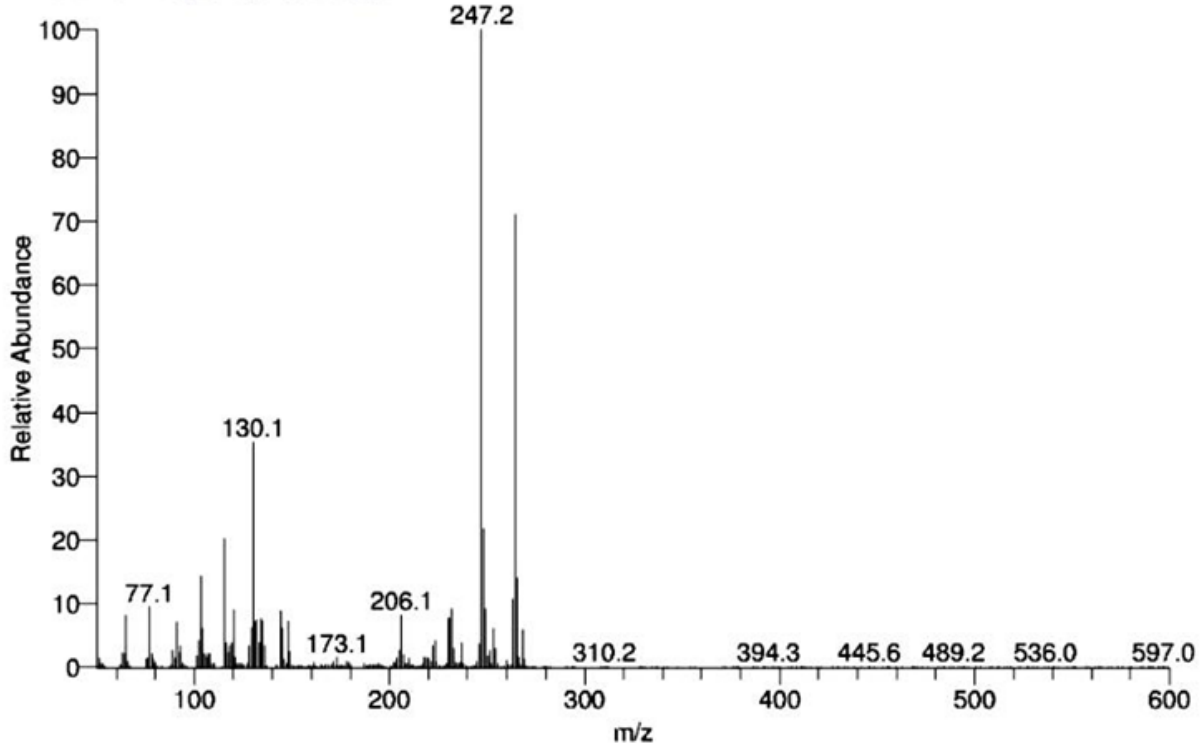

Figure VI:- Mass spectra of GE-MP 


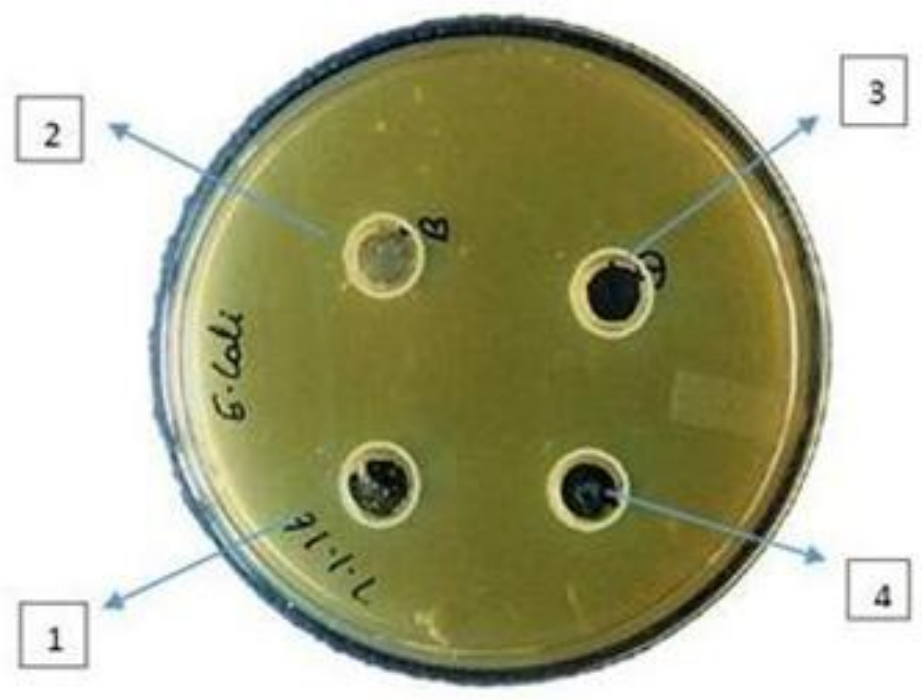

[A]

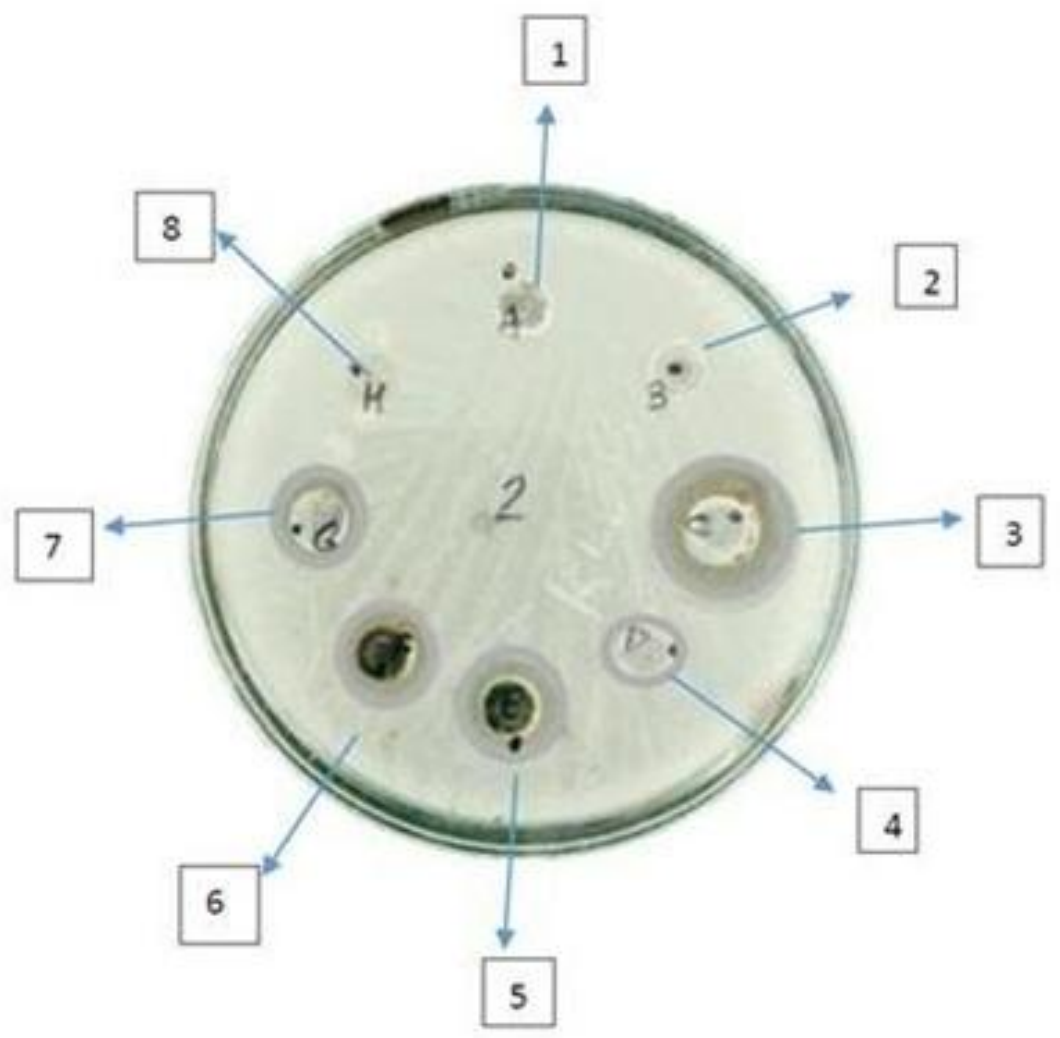

[B]

Figure VII:-Photographs showing Antibacterial activity [A] and Antifungal activity [B] (Numbering is done as shown in Table II and Table III). 


\section{References:-}

1. https://en.wikipedia.org/wiki/Guar_gum

2. Kays SE, Morris JB, Kim Y(2006):Total and soluble dietary fiber variation in cyamopsistetragonoloba (L.) Taub. (Guar) genotypes. J Food Quality,29:383-391.

3. Singh A.V, Sharma N(2011):Characterisation and applications of synthesised cation exchanger guar gum sulphonic acid (GSA) resin for removaland recovery of toxic metal ions from industrial wastewater (Available on website http://www.wrc.org.za)

4. Ventola C.L.(2015):The antibiotic resistance crisis: Part 1: Causes and threats. P T, 40, 277-283.

5. SiedenbiedelF.,Tiller J.C.(2012): Antimicrobial polymers in solution and on surfaces: Overview and functionalprinciples. Polymers, 4, 46-71.

6. Muñoz-Bonilla A., Fernández-García M.(2012): Polymeric materials with antimicrobial activity. Prog. Polym. Sci., 37, 281-339.

7. Kenawy E.R., Worley S.D., Broughton R.(2007): The chemistry and applications of antimicrobial polymers: A state-of-the-art review,Biomacromolecules, 8, 1359-1384.

8. Jain A., Duvvuri L.S., Fara S., Beyth N., Domb A.J., Khan W(2014): Antimicrobial polymers,

9. Adv. Healthc. Mater, 3, 1969-1985.

10. Daljit S.A.,Jasleen K (1999):Int J. Antimicro. Agents, 2, 257-262.

11. Adegboye M.F.,Babalola O.O., and Akinpelu D.A. (2012): Issues of resistance of pathogens to antimicrobial agents,ScientificResearch Essays, vol. 7, no. 41, pp. 3468-3478.

12. Worley S.D., Broughton, Roy (2007): American Chemical Society, 8(5), 1359-1364.

13. Xue Y., Xiao H., Zhang Y.(2015): Antimicrobial polymeric materials with quaternary ammonium and phosphoniumsalts,Int. J. Mol. Sci., 16, 3626-3655.

14. Leceta I., Guerrero P., Ibarburu I., Due nas M.T., and K. de la Caba (2013): Characterization and antimicrobial analysis of chitosan based films,Journal of Food Engineering, vol. 116, no. 4,pp. 889-899. 